\title{
Diagnostic Value of Imaging Modalities for COVID-19: Scoping Review
}

\author{
Rowa Aljondi ${ }^{*}$ PhD; Salem Alghamdi*, PhD \\ Department of Applied Radiologic Technology, College of Applied Medical Sciences, University of Jeddah, Jeddah, Saudi Arabia \\ *all authors contributed equally
}

\section{Corresponding Author:}

Rowa Aljondi, $\mathrm{PhD}$

Department of Applied Radiologic Technology

College of Applied Medical Sciences

University of Jeddah

Al Sharafeyah

Jeddah, 23218

Saudi Arabia

Phone: 966530550559

Email: rowaaljondi@gmail.com

\section{Abstract}

Background: Coronavirus disease (COVID-19) is a serious infectious disease that causes severe respiratory illness. This pandemic represents a serious public health risk. Therefore, early and accurate diagnosis is essential to control disease progression. Radiological examination plays a crucial role in the early identification and management of infected patients.

Objective: The aim of this review was to identify the diagnostic value of different imaging modalities used for diagnosis of COVID-19.

Methods: A comprehensive literature search was conducted using the PubMed, Scopus, Web of Science, and Google Scholar databases. The keywords diagnostic imaging, radiology, respiratory infection, pneumonia, coronavirus infection and COVID-19 were used to identify radiology articles focusing on the diagnosis of COVID-19 and to determine the diagnostic value of various imaging modalities, including x-ray, computed tomography (CT), ultrasound, and nuclear medicine for identification and management of infected patients.

Results: We identified 50 articles in the literature search. Studies that investigated the diagnostic roles and imaging features of patients with COVID-19, using either chest CT, lung ultrasound, chest X-ray, or positron emission topography/computed tomography (PET/CT) scan, were discussed. Of these imaging modalities, chest x-ray and CT scan are the most commonly used for diagnosis and management of COVID-19 patients, with chest CT scan being more accurate and sensitive in identifying COVID-19 at early stages. Only a few studies have investigated the roles of ultrasound and PET/CT scan in diagnosing COVID-19.

Conclusions: Chest CT scan remains the most sensitive imaging modality in initial diagnosis and management of suspected and confirmed patients with COVID-19. Other diagnostic imaging modalities could add value in evaluating disease progression and monitoring critically ill patients with COVID-19.

(J Med Internet Res 2020;22(8):e19673) doi: 10.2196/19673

\section{KEYWORDS}

diagnostic imaging; radiology; COVID-19; respiratory infection; pneumonia; imaging; CT; infectious disease; diagnosis; review

\section{Introduction}

Coronavirus disease (COVID-19) is a viral respiratory disease that first emerged in December 2019, when a cluster of patients with unknown pneumonia was reported in Wuhan City in Hubei Province in China. The causative agent of this unknown pneumonia was a novel coronavirus, later known as novel coronavirus pneumonia (NCP) [1,2]. This virus was then renamed severe acute respiratory syndrome coronavirus 2 (SARS-CoV-2) by the International Committee on Taxonomy of Viruses based on phylogeny, taxonomy, and established practice $[3,4]$. Compared with previous coronaviruses, such as severe acute respiratory syndrome coronavirus (SARS-CoV) and the Middle East respiratory syndrome coronavirus 
(MERS-CoV), SARS-CoV-2 is highly contagious and transmissible from person to person [5]. The disease caused by SARS-CoV-2 was officially named coronavirus disease 2019 (COVID - 19) by the World Health Organization (WHO) [6]. It quickly spread to other countries worldwide, causing an increasing number of deaths [7,8]. Accordingly, on January 30, 2020, the WHO declared COVID_19 an international public health emergency [9].

The most common clinical symptoms are fever, dry cough, fatigue, and gradual development of dyspnea [10-12]. The current gold standard clinical diagnostic tool for COVID-19 is the reverse transcription-polymerase chain reaction (RT-PCR) analysis of specimens from the respiratory tract. However, this test shows high false negative results due to inadequate cellular material or errors in detection and extraction techniques during nasopharyngeal swab sampling [13-15]. With an increasing number of infected patients and a shortage of RT - PCR testing kits in affected areas, alternative diagnostic and screening strategies are needed [16]. As such, diagnostic imaging now plays a critical role in identifying and assessing the progression of COVID-19 [17].

Recently, radiological literature has focused on chest computed tomography (CT) findings in COVID-19 [18-23]. Excessive use of CT scans can place a substantial burden on radiology departments in practice and increase the risk of infection in CT units [19]. However, other imaging modalities, such as chest $\mathrm{x}$-ray, ultrasound, and positron emission topography/computed tomography (PET/CT), have also been used in the diagnosis and management of patients with COVID-19 [19]. Thus, radiologists should be aware of the roles and diagnostic value of various other imaging modalities for COVID-19 that can help manage disease progression [7,24]. In this literature review, we discuss the diagnostic value of each imaging modality commonly used in the diagnosis and evaluation of patients with COVID-19.

\section{Methods}

A literature search was performed on April 28, 2020, using the PubMed, Scopus, and Web of Science databases. The keywords diagnostic imaging, radiology, respiratory infection, pneumonia, coronavirus infection, and COVID-19 were used to identify articles focusing on the diagnostic value of different imaging modalities used for diagnosis and management of patients with COVID-19. To increase the sensitivity of the search, Google Scholar was employed with the same keywords, capturing the most recently published articles in the field of imaging for COVID-19. This Google Scholar search was limited to selected keywords in the article titles due to the large number of records identified from the literature. All searches were limited to articles published in 2020, with consideration of the earliest date of confirmed COVID-19 reports. For inclusion in this literature review, articles were required to be original research, peer-reviewed, and written in English. Nonscientific commentary and news articles were excluded. Figure 1 illustrates the literature search process and article identification.

Figure 1. Flowchart showing the article identification and selection process.

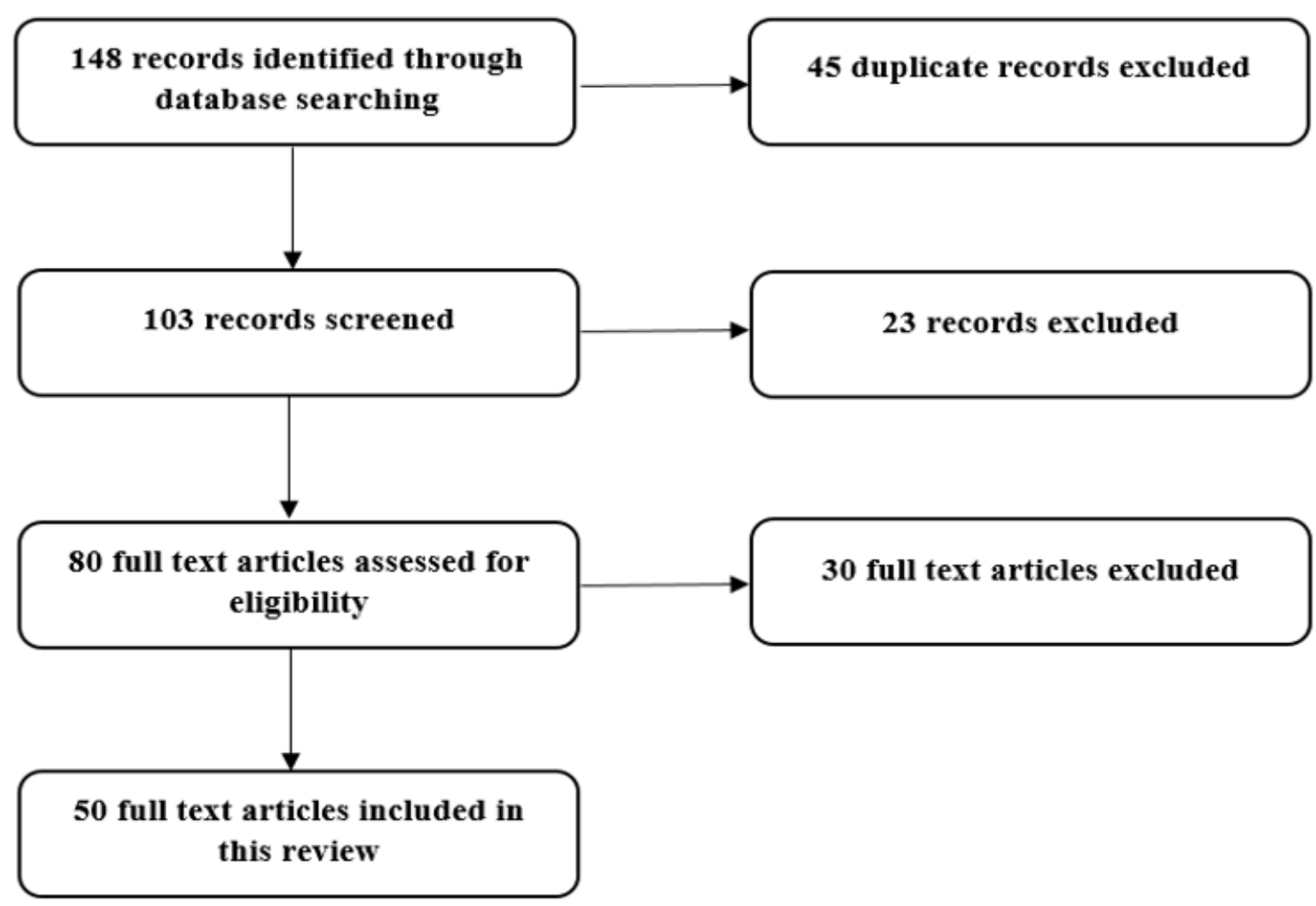




\section{Results}

In the literature search, 50 articles were identified, covering areas such as chest CT scan, chest radiography (x-ray), nuclear medicine, and ultrasound in diagnosis and management of suspected and confirmed cases of COVID-19 (Multimedia Appendix 1) [2,8,13-15,18-22,25-65]. The selected articles are discussed in the following sections.

\section{Discussion}

\section{Computed Tomography}

Chest computed tomography (CT) is considered to be the primary diagnostic modality for examining patients with COVID-19 [20,25,26]. A large number of existing studies have investigated the CT image manifestations in COVID-19 cases $[8,19,25,26,28-30,32,64]$. The most common chest CT imaging features of COVID-19 pneumonia include peripheral ground-glass opacities (GGOs) and consolidation in the lower and middle lung regions, usually bilaterally distributed and with multi-lobar involvement (Figure 2) [19,26,31,32,63]. On the initial CT images, some patients with COVID-19 have pulmonary nodules that increase in size and number in follow-up CT [22,25]. Regarding infection duration, Bernheim et al [20] identified the most common CT findings at a longer time after symptom onset, including consolidation, linear opacities, bilateral and peripheral disease, crazy paving pattern, and reserved halo sign, which indicate greater total lung involvement. However, pneumothorax, pleural effusion, lymphadenopathy, pericardial effusion, and lung cavitation are uncommon findings on chest CT imaging of patients with COVID-19 that can be seen with disease progression in follow-up CT images [22].

The chest CT patterns of COVID-19 pneumonia are likely related to the pathological changes in the lungs [27,29]. Although the pathological process of lung injury in patients with COVID-19 pneumonia has not yet been studied, recent research has reported that SARS-CoV-2 shares a similar pneumonia pathogenesis to the severe acute respiratory syndrome (SARS) and Middle East respiratory syndrome (MERS) coronaviruses [31,33,64]. In SARS patients, angiotensin-converting enzyme 2 is a molecule that is potentially involved in the development and progression of acute lung failure [33,64]. The SARS virus induces lung injury by affecting this enzyme, which contributes to injury of pulmonary epithelial cells, diffuse alveolar damage, and edema [33,64]. These results may explain the pathological basis of GGO and consolidation as well as the rapid changes in chest $\mathrm{CT}$ imaging in patients with COVID-19 [33,64].

The chest CT manifestations of COVID-19 vary at different stages of the disease, which helps differentiate the diagnosis of COVID-19 from those of other known pneumonia viruses, such as mycoplasma pneumonia and bacterial pneumonia [29,31,34]. In pneumonia caused by SARS and MERS, the chest CT shows a unifocal involvement of lung lesions more than multifocal involvement, which is found on the chest CT images of patients with COVID-19 [64]. In patients with MERS, the GGOs are mainly distributed in the subpleural and basilar lung regions in the chest CT images. The chest CT imaging of patients with SARS shows that multiple GGOs are distributed in the periphery of the lung, with interlobular septal thickening and intralobular interstitial hyperplasia. These findings are similar to the chest CT features of patients with COVID-19 [31]. With the progression of COVID-19 pneumonia, the number of GGOs increases and the consolidations become denser [64]. These findings indicate that there are differences as well as similarities between viruses of the same family [29,31,34].

CT imaging has proven to be diagnostic in early stages of COVID-19 [25,29]. In a recent report involving 1014 patients in Wuhan, China, the sensitivity, specificity, diagnostic accuracy, positive predictive value, and negative predictive value for identifying COVID-19 infection using RT-PCR results as reference standards were $97 \%, 25 \%, 68 \%, 65 \%$, and $83 \%$, respectively [14]. Most patients with COVID-19 who initially showed negative RT-PCR results presented lung abnormalities on their chest CT images [13-15,35]. Moreover, abnormal chest CT findings have been observed in all patients with positive laboratory-confirmed COVID-19 infection by RT-PCR [2]. Similarly, Li and Xia [64] evaluated the diagnostic performance of chest CT for COVID-19 in cases confirmed by nucleic acid test and found that the initial chest CT scan showed a low misdiagnosis rate of COVID-19 viral pneumonia (3.9\%) as a common infection. These studies suggest that chest CT imaging is an effective method for early diagnosis of COVID-19, particularly in regions with a shortage of RT - PCR testing kits.

The diagnostic value of chest CT examination mainly lies in its short examination time and high resolution in the detection and classification of lung lesions. Additionally, CT scanning is highly reproducible and easy to perform [29], and it provides a rapid and accurate estimation of disease progression. The main advantages of chest $\mathrm{CT}$ in detecting lung lesions in patients with COVID-19 are early characterization of lung lesions, assessment of disease severity, and improvement of lung lesions during treatment [29]. Thus, numerous studies emphasize follow-up CT examination in COVID-19 patients [21,25,26,29,36,42,64]. Among these studies, Pan et al [25] examined initial and follow-up imaging features in patients with confirmed COVID-19 using high resolution CT scans; they found diverse and rapidly changing imaging signs with disease progression in COVID-19 pneumonia. $\mathrm{Li}$ and $\mathrm{Xia}$ [64] also reported that $75 \%$ of their patients with COVID-19 showed disease progression in follow-up CT examination. One other study that examined changes in CT image findings from initial diagnosis of COVID-19 pneumonia until patient recovery observed that lung abnormalities increased to consolidations approximately 10 days after initial symptom onset [21]. In patients who recovered from COVID-19 pneumonia, chest CT abnormalities gradually decreased two weeks after initial onset of symptoms. Therefore, rapid and accurate diagnosis of COVID-19 based on CT imaging features in conjunction with clinical and laboratory findings may be useful in early control of potential transmission and optimizing management of patients with suspected disease so they can be treated and isolated promptly $[36,64]$.

While chest CT imaging is the most sensitive modality for the early detection of lung disease and management of patients with COVID-19, it has low specificity for distinguishing lung lesions 
of COVID-19 pneumonia from findings of other viral pneumonia caused by SARS and MERS [14,64]. In addition, it poses an increased risk of infection transmission to other patients or health care workers; as such, thorough cleaning is required, causing downtime of the scanning room and consumption of personal protection equipment [38]. Accordingly, the American College of Radiology (ACR) does not recommend using a CT scan for diagnosis of COVID-19 as a first-line test [41]. Moreover, before scanning subsequent patients, appropriate infection control techniques should be applied [41]. To control this pandemic, chest $\mathrm{CT}$ imaging should be reserved for screening patients with COVID-19 pneumonia complications $[18,37,41]$.

Figure 2. Chest computed tomography findings in patients with coronavirus disease [63]. (a) Ground-glass opacities, (b) consolidations, (c) consolidations with ground-glass opacities, (d) solid nodules.
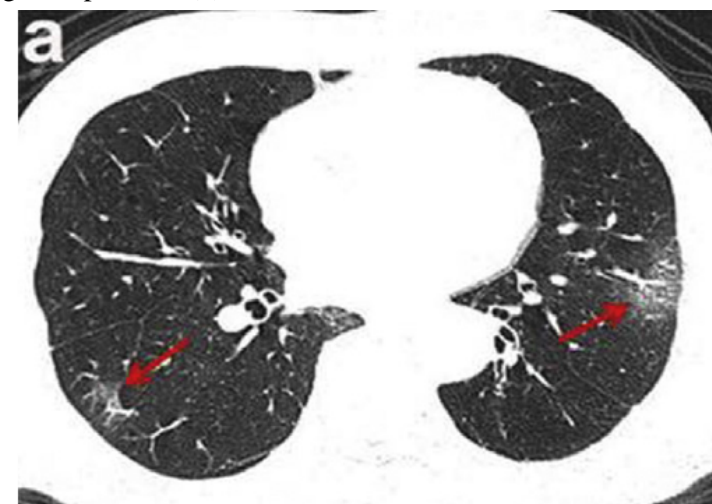

8

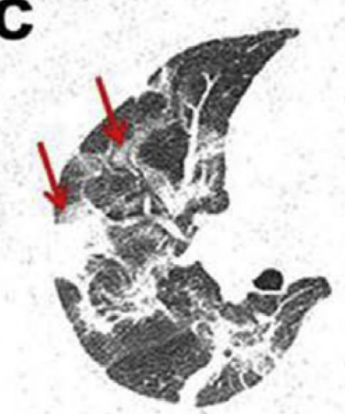

$\mathbf{m}$

\section{Chest Radiography}

Chest $\mathrm{x}$-ray is the most commonly used diagnostic imaging modality for patients with COVID-19 [44]. Still, chest radiography has limited sensitivity for COVID-19 in early stage of infection, as initial chest x-rays usually indicate normal lung appearance $[18,19]$. Therefore, it was not recommended as the first-line imaging modality for diagnosis of suspected COVID-19 patients [45]. Several studies report that chest x-ray often shows no image abnormalities in patients with COVID-19 at early stages $(<2-4$ days) $[18,19]$. Wong et al [18] reported that the severity and abnormalities of chest $x$-ray in COVID-19 patients appeared 10 to 12 days after initial symptom onset. Using the RT-PCR results as the gold standard, the reported sensitivity of baseline chest x-ray for diagnosis of COVID-19 in mild to moderate cases was $69 \%$ [18]. When imaging is abnormal in severe cases, the most common features of chest $\mathrm{x}$-rays are consolidation and GGOs with bilateral involvement and/or peripheral distribution (Figure 3) [18,28,43]. In COVID-19 patients, pleural effusions, lung cavitation, and pneumothorax were reported as rare findings on chest $\mathrm{X}$-rays and could occur late in the disease course [22].
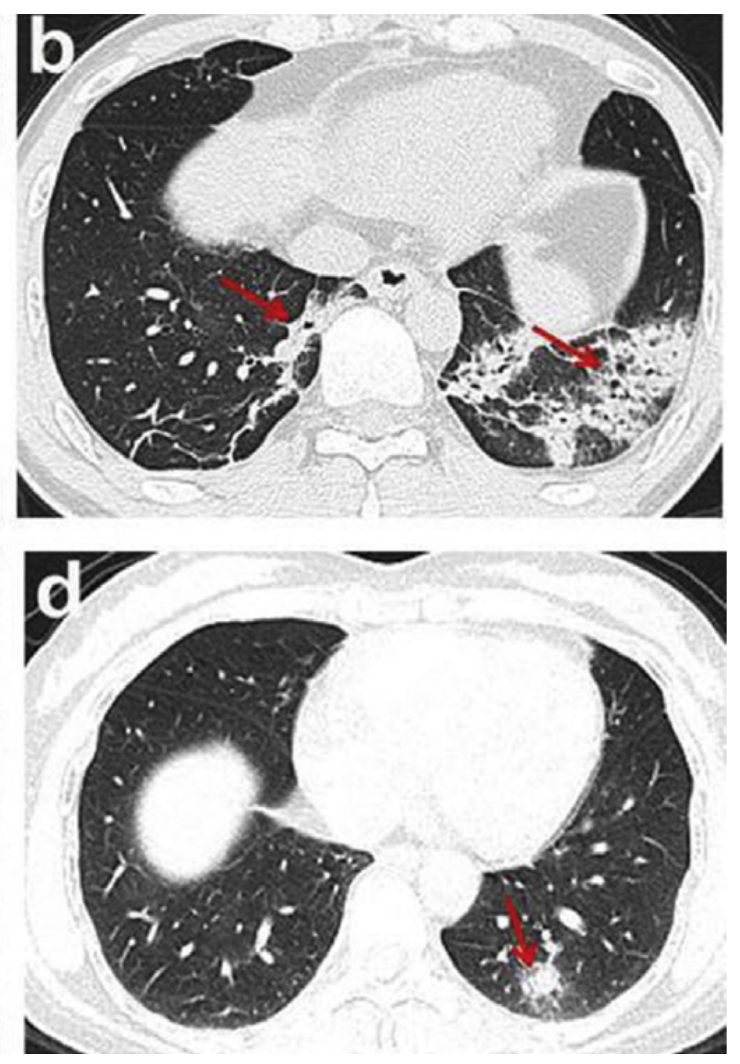

As the pandemic progresses, chest x-rays could play a vital role in disease identification for patients with high clinical suspicion of COVID-19 [44]. The ACR recommends using portable chest $\mathrm{X}$-ray units to reduce the risk of cross-infection in radiology departments [41]. The advantages of using a portable chest x-ray unit is that it can detect the most common manifestations and patterns of COVID-19 lung abnormality in clinically confirmed cases of COVID-19, thereby limiting use of the CT scanner [44]. Jacobi et al [44] suggested using portable chest X-ray units for the diagnosis and follow-up of patients with high clinical suspicion of COVID-19 due to their cost-effectiveness and widespread availability; this modality can be used in emergency or intensive care units to minimize infection risks [44].

The limitation of chest $\mathrm{x}$-ray imaging is its lack of sensitivity in detecting lung lesions in the early stage of COVID-19 pneumonia $[18,19,43]$. In addition, there is a paucity of reported specificity and diagnostic accuracy of chest $\mathrm{x}$-ray in various stages of COVID-19 pneumonia. Thus, it is difficult to use chest $\mathrm{X}$-rays to distinguish COVID-19 from pneumonia caused by other coronaviruses such as MERS and SARS. The positive predictive value and negative predictive value of chest $\mathrm{X}$-rays for COVID-19 pneumonia have not yet been established. 
Figure 3. Chest $x$-ray findings in a patient with coronavirus disease. (A) Patchy consolidations, (B) pleural effusion, (C) perihilar distribution, (D) peripheral distribution [18].

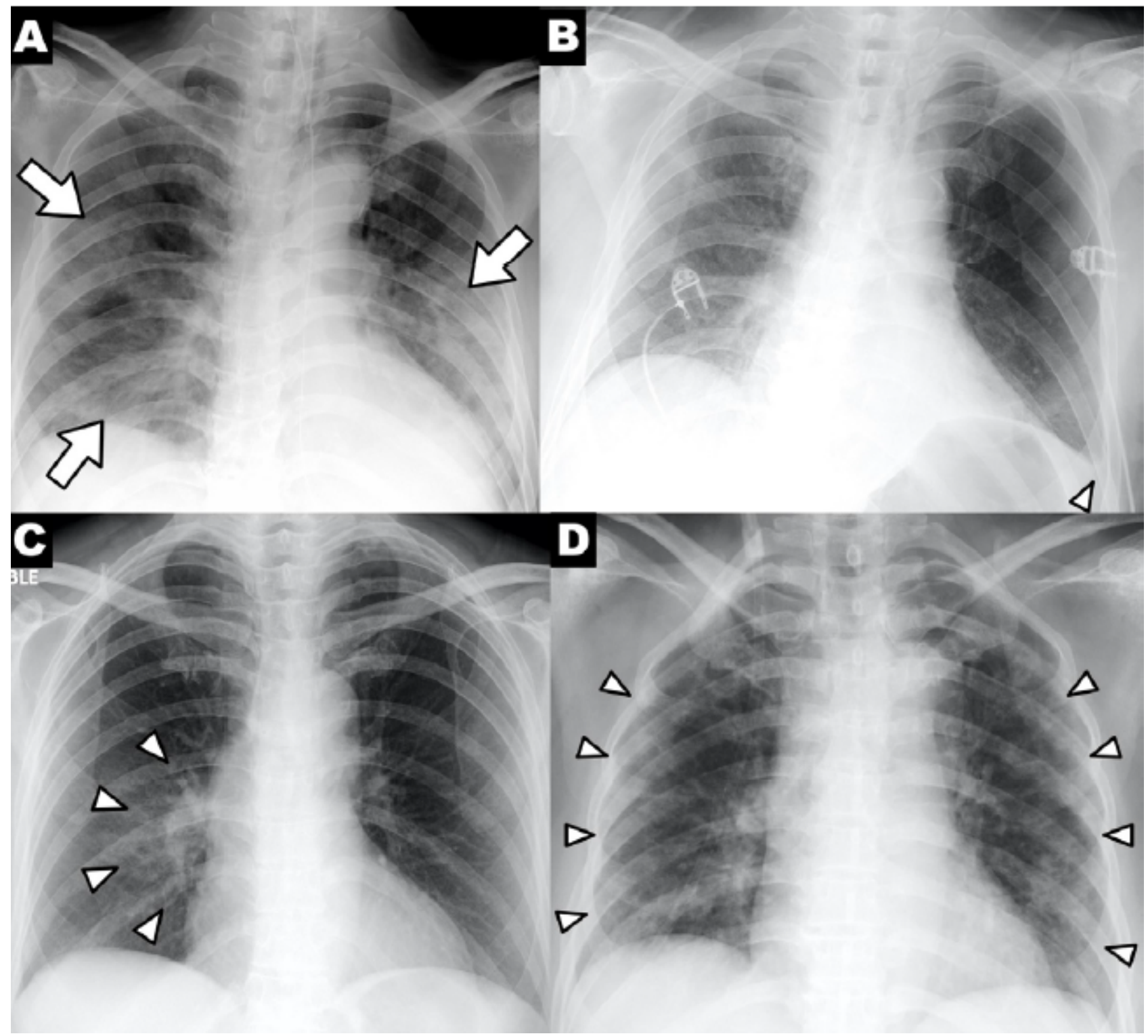

\section{Nuclear Medicine}

Combined positron emission topography/computed tomography $(\mathrm{PET} / \mathrm{CT})$ is an established nuclear medicine method for assessing and monitoring several lung diseases. ${ }^{18} \mathrm{~F}$-labelled fluorodeoxyglucose $\left({ }^{18} \mathrm{~F}\right.$-FDG) is the most commonly used radiotracer in PET/CT imaging; it shows metabolic activity in inflammatory cells [46]. However, the role of nuclear medicine in the diagnosis and management of COVID-19 appears to be limited [47].

Qin et al [48] reported the findings of ${ }^{18}$ F-FDG-PET/CT imaging in a case series of four patients with COVID-19. All patients presented with peripheral GGOs and/or consolidation in pulmonary lobes, showing high tracer uptake with a maximum standardized uptake value (SUV max) range of 1.8-12.2. In addition, increased nodal FDG uptake was observed in three out of four patients. Although lymphadenopathy was rare in CT imaging findings in patients with COVID-19 infection [32], these high tracer uptakes in pulmonary or lymph nodal lesions reflect a significant inflammatory burden, which is a hallmark of COVID-19 pulmonary infections [48]. As a noninvasive imaging modality, FDG-PET/CT can play a potential role in the evaluation of lung function in COVID-19 pneumonia.

Zou and Zhu [49] also reported the case of a COVID-19 patient who was scanned using ${ }^{18}$ F-FDG-PET/CT. They observed a positive FDG uptake (SUV max 4.9) in the right lung and increased accumulation of FDG in the right hilar and right paratracheal lymph nodes (Figure 4). In this case study, accumulation of FDG was noted in the bone marrow. In another case study reported by Czernin et al [50] of a 53-year-old patient with a neuroendocrine pancreatic tumor who was referred for staging and scanned with ${ }^{18} \mathrm{~F}-\mathrm{FDG}-\mathrm{PET} / \mathrm{CT}$, they found positive uptake (SUV max 5.5) in a new hypermetabolic area in the right lower and upper lobes. This tracer uptake correlated topographically to predominantly peripheral and sub-pleural GGOs with beginning, partly round-shaped consolidations. The patient was asymptomatic when the PET scan was performed; however, COVID-19 infection was later confirmed [50]. These 
observations suggest the diagnostic value of nuclear medicine imaging in the early stages of COVID-19, especially when clinical symptoms are unspecific in patients referred for other clinical concerns. As the progression and severity of the disease can harm other organs, such as the kidneys, bone marrow, heart and gastrointestinal tract, ${ }^{18} \mathrm{~F}-\mathrm{FDG}$-PET/CT scans can provide a whole-body noninvasive assessment to detect damage in chronical and concomitant organs [47].

As an imaging modality, FDG PET/CT offers added value in diagnostic complications caused by COVID-19, observation of disease progression, and treatment responses [46,47]. While PET/CT cannot be routinely used in an emergency setting for COVID-19, this imaging modality could play a complementary diagnostic role in disease management [47]. ${ }^{18}$ F-FDG PET/CT may hold special diagnostic value in estimating the extent of organ involvement during the course of COVID-19 and in monitoring treatment efficiency. It also may help predict the recovery time of patients with COVID-19 [47].

Based on available evidence, the advantage of using ${ }^{18} \mathrm{~F}-\mathrm{FDG}$ $\mathrm{PET} / \mathrm{CT}$ for patients with COVID-19 is its sensitivity in detecting, diagnosing, and monitoring pathophysiological changes in inflamed and infected lung lesions [51]. However, recent published studies of FDG PET/CT for COVID-19 have been limited to small sample sizes and case reports $[48,49]$. Further investigations are required to identify the SUV cutoffs for different lung lesions in various stages of the disease to define the potential diagnostic accuracy and limitations of $\mathrm{PET} / \mathrm{CT}$ scan in detecting lung lesions for COVID-19 pneumonia. Although radionuclide pulmonary ventilation and perfusion may play roles in the diagnosis of pulmonary embolism in patients with COVID-19, these modalities are not recommended for use in clinical practice during the pandemic due to the increased risk of infection transmission [52].

Figure 4. Fluorodeoxyglucose positron emission topography/computed tomography (FDG PET/CT) imaging findings in a patient with coronavirus disease. (A) The PET maximum intensity projection image shows an FDG-avid mass in the right lung with a maximum standardized uptake value of 4.9, as well as increased accumulation of FDG in the right hilar lymph nodes, in the right paratracheal stripe (arrowhead), and in the bone marrow. The axial images of the low-dose CT scan (B) and the PET/CT fusion (C) show ground-glass opacities in the right upper lobe with areas of focal consolidation (arrows) and focal opacities in the right middle and left upper lobes (arrows). Follow-up CT axial images obtained 4 days later (D) show lesion progression in the middle and bilateral upper lobes, with newly developed focal opacities in the left lower and upper lobes (arrows) [49].
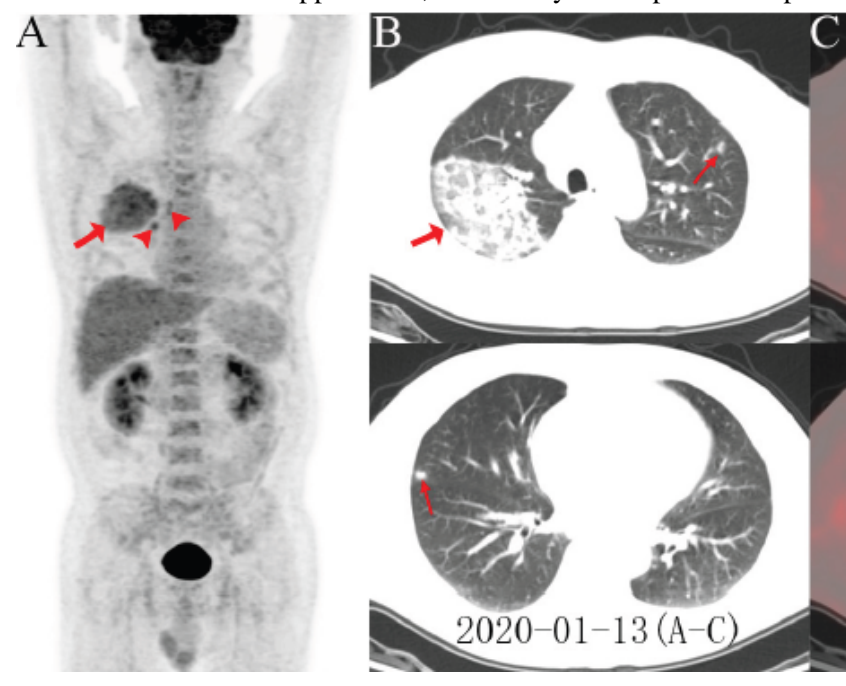

\section{Ultrasound}

Commonly used for early diagnosis of pneumonia, lung ultrasound is an alternative to chest x-ray or CT scan $[53,54]$. The diagnostic accuracy of lung ultrasound has been found to be significantly better than that of chest $\mathrm{x}$-ray in identifying the most common lung pathologies, such as consolidation, pneumothorax, pleural effusion, and interstitial syndrome [55]. The most common ultrasonography features of patients with confirmed COVID-19 include thickened pleural lines with irregularities, B-lines in various patterns, small peripheral consolidations, absence of pleural effusions, and appearance of A-lines during recovery [56]. Lung ultrasonography has specific features for alveolar-interstitial lung disease, including viral pneumonia and adult respiratory distress syndrome (ARDS), which distinguish it from bacterial pneumonia. These features are represented by the B-lines, small subpleural consolidation, and irregular pleural line [57]. In a case report of a young man infected with COVID-19 [59], his lung ultrasound results clearly showed signs suggestive of interstitial-alveolar damage, including areas of white lung, irregular pleural line with subpleural consolidations, and thick irregular vertical artifacts (B-lines) (Figure 5).

The advantages of lung ultrasound for detecting lung lesions in patients with COVID-19 are that it gives similar results to chest CT and it is superior to standard chest radiography $[43,56]$. Lomoro et al [43] performed lung ultrasound, chest radiography, and CT scans of confirmed COVID-19 patients and found an association between lung ultrasound features and CT findings for GGOs and consolidation. This could aid the rapid diagnosis and management of COVID-19 pneumonia and its progression toward ARDS $[43,57]$. A notable limitation of lung ultrasound is that aerated lungs may block transmission of ultrasonography, preventing the detection of deep lesions within the lung $[57,58]$. When pneumonia does not extend to the pleural surface, a CT scan is required to identify disease progression [57]. 
Taking chest CT as the gold standard, lung ultrasound showed relatively high diagnostic consistency value and diagnostic coincidence rate in asymptomatic patients with COVID-19 [60]. The positive predictive value and negative predictive value were $100 \%$ and $85.71 \%$, respectively [60]. Thus, lung ultrasound can be used as a screening method for lung involvement at different stages of COVID-19 pneumonia [57,58]. In the early stage of the disease, the focal B-line was seen in the lung ultrasound, whereas in more severe and progressive stages, thickening of the plural line and irregular B-lines were found in patients with fibrosis and alveolar interstitial syndrome [57]. Lu et al [65] investigated the clinical value of ultrasound in the diagnosis of lung lesions at different stages of COVID-19. They found that the diagnostic accuracy $(93.3 \%)$, sensitivity (100.0\%), and specificity $(85.7 \%)$ of bedside ultrasound are high for severe lung lesions in COVID-19 patients; however, they are relatively low for mild (sensitivity $68.8 \%$, specificity $85 \%$, diagnostic accuracy $76.7 \%$ ) and moderate (sensitivity $77.8 \%$, specificity $76.2 \%$, diagnostic accuracy $76.7 \%$ ) lung lesions [65]. This study suggests that the use of nonionizing and dynamic ultrasound examination should be further considered in critically ill patients with suspected or documented COVID-19 infection to detect the severity of lung lesions [65]. The additional advantage of lung ultrasound is that it can be used in the emergency department or in the intensive care unit for scanning COVID-19 patients due to its portability, safety, absence of radiation, ease of use, repeatability, and low cost [59]. However, strict protection and operating procedures during the examination should be employed to minimize infection risk [65].
During the COVID-19 pandemic, lung ultrasound was rapidly established in Italy as a diagnostic tool in patients with suspected COVID-19 infection [61]. Their application of lung ultrasound scores offers added value for determining severity of lung involvement in infected patients. Vetrugno et al [61] also noted a reduction in the use of CT scans and chest X-ray along with improved management of patients. Thus, lung ultrasound may be helpful when planning a suitable diagnostic workup, depending on the patient's clinical condition and available technological resources.

Lung ultrasound could also play a crucial role in the diagnosis and monitoring of pregnant women with COVID-19 [62]. To our knowledge, there is limited data on pregnant women with COVID-19 infection. In a case study of 9 pregnant women with COVID-19, chest CT scans were used and showed multiple patchy ground-glass shadows in the lungs, similar to those of nonpregnant women with COVID-19 [39]. Liu et al [40] reported similar chest $\mathrm{CT}$ imaging features in pregnant women with COVID-19 but with more severe consolidations. In their study, a low-dose technique was used for CT scanning of pregnant women; this technique was sufficient to detect lesions but reduced the image quality [40]. While chest CT was the first-choice modality for early detection and assessment of disease severity, special attention was required in follow-up diagnosis and management of pregnant women with COVID-19. As lung ultrasound can reveal certain specific signs in patients with respiratory involvement of COVID-19 [65], it can be used in the diagnosis of pregnant women with COVID-19 [62].

Figure 5. Lung ultrasound findings in a patient with coronavirus disease. Irregular plural lines (A, C, E, and F, within the white boxes); thick irregular vertical artifacts (A, B, C, D, and E, white arrows); subpleural consolidations (B and D, white arrowheads); and areas of white lung (F, red arrow) [59].

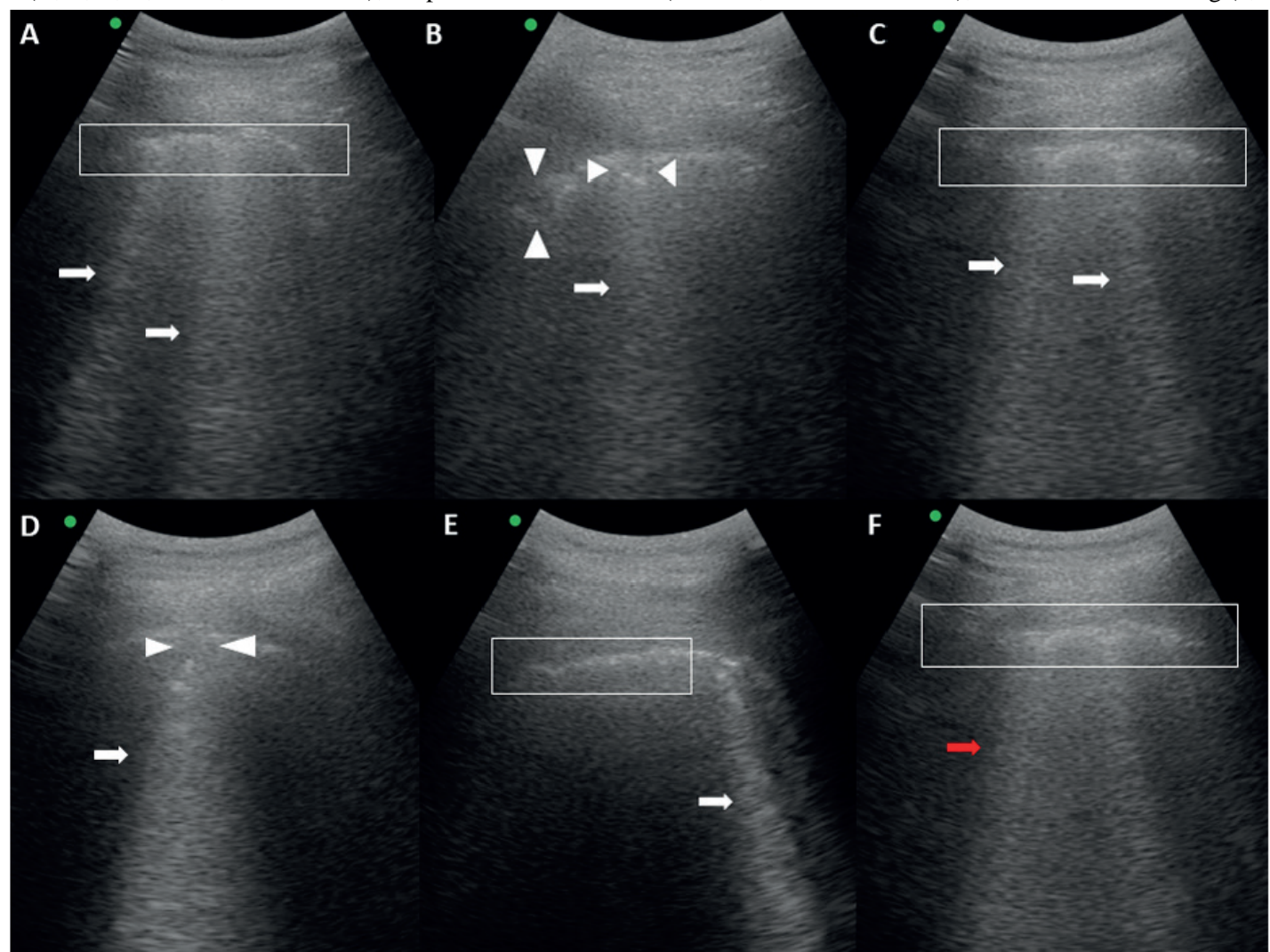




\section{Conclusion}

In this literature review, the value and roles of different imaging modalities for the diagnosis and management of COVID-19 were discussed. Chest X-ray and CT scan are thoracic imaging techniques with key diagnostic value in suspected cases of
COVID-19. While PET/CT and ultrasound may not be routinely used in diagnosing COVID-19, these modalities could play complementary roles and add value in managing disease progression. Ultimately, early and accurate diagnosis of patients infected with COVID-19 can effectively control disease progression.

\section{Acknowledgments}

The authors thank Dr Adnan Al-Homaidan, President of the University of Jeddah, and the Vice-President for Graduate Studies and Scientific Research, Dr Obaid Al-Modaf, for their support and encouragement of research related to COVID-19. Also, the authors would like to thank the College of Applied Medical Sciences and the department of Applied Radiologic Technology in the University of Jeddah for their full support. This work received no funding.

\section{Conflicts of Interest}

None declared.

\section{Multimedia Appendix 1}

Summary of the selected articles in the literature based on the different imaging modalities and their diagnostic value for COVID-19. [PNG File, 41 KB-Multimedia Appendix 1]

\section{References}

1. He F, Deng Y, Li W. Coronavirus disease 2019: What we know? J Med Virol 2020 Jul;92(7):719-725 [FREE Full text] [doi: $10.1002 / j m v .25766]$ [Medline: $\underline{32170865]}$

2. Huang C, Wang Y, Li X, Ren L, Zhao J, Hu Y, et al. Clinical features of patients infected with 2019 novel coronavirus in Wuhan, China. Lancet 2020 Feb;395(10223):497-506. [doi: 10.1016/s0140-6736(20)30183-5]

3. Gorbalenya A, Baker SC, Baric RS, de Groot RJ, Drosten C, Gulyaeva AA, et al. Severe acute respiratory syndrome-related coronavirus - The species and its viruses, a statement of the Coronavirus Study Group. bioRxiv 2020 Feb 11:preprint. [doi: 10.1101/2020.02.07.937862]

4. Coronaviridae Study Group of the International Committee on Taxonomy of Viruses. The species Severe acute respiratory syndrome-related coronavirus: classifying 2019-nCoV and naming it SARS-CoV-2. Nat Microbiol 2020 Apr 2;5(4):536-544 [FREE Full text] [doi: $\underline{10.1038 / \mathrm{s} 41564-020-0695-\mathrm{z}]}$ [Medline: $\underline{\text { 32123347] }}$

5. Yan Y, Shin WI, Pang YX, Meng Y, Lai J, You C, et al. The First 75 Days of Novel Coronavirus (SARS-CoV-2) Outbreak: Recent Advances, Prevention, and Treatment. Int J Environ Res Public Health 2020 Mar 30;17(7):2323 [FREE Full text] [doi: 10.3390/ijerph17072323] [Medline: 32235575]

6. Lai C, Shih T, Ko W, Tang H, Hsueh P. Severe acute respiratory syndrome coronavirus 2 (SARS-CoV-2) and coronavirus disease-2019 (COVID-19): The epidemic and the challenges. Int J Antimicrob Agents 2020 Mar;55(3):105924 [FREE Full text] [doi: 10.1016/j.ijantimicag.2020.105924] [Medline: $\underline{32081636}$ ]

7. Kanne J. Chest CT Findings in 2019 Novel Coronavirus (2019-nCoV) Infections from Wuhan, China: Key Points for the Radiologist. Radiology 2020 Apr;295(1):16-17 [FREE Full text] [doi: 10.1148/radiol.2020200241] [Medline: 32017662]

8. Zhou S, Wang Y, Zhu T, Xia L. CT Features of Coronavirus Disease 2019 (COVID-19) Pneumonia in 62 Patients in Wuhan, China. American Journal of Roentgenology 2020 Jun;214(6):1287-1294. [doi: 10.2214/ajr.20.22975]

9. Sohrabi C, Alsafi Z, O'Neill N, Khan M, Kerwan A, Al-Jabir A, et al. World Health Organization declares global emergency: A review of the 2019 novel coronavirus (COVID-19). Int J Surg 2020 Apr;76:71-76 [FREE Full text] [doi:

10.1016/j.ijsu.2020.02.034] [Medline: 32112977]

10. Zhang G, Zhang J, Wang B, Zhu X, Wang Q, Qiu S. Analysis of clinical characteristics and laboratory findings of 95 cases of 2019 novel coronavirus pneumonia in Wuhan, China: a retrospective analysis. Respir Res 2020 Mar 26;21(1):74 [FREE Full text] [doi: 10.1186/s12931-020-01338-8] [Medline: 32216803]

11. Chen N, Zhou M, Dong X, Qu J, Gong F, Han Y, et al. Epidemiological and clinical characteristics of 99 cases of 2019 novel coronavirus pneumonia in Wuhan, China: a descriptive study. Lancet 2020 Feb 15;395(10223):507-513 [FREE Full text] [doi: 10.1016/S0140-6736(20)30211-7] [Medline: 32007143]

12. Huang C, Wang Y, Li X, Ren L, Zhao J, Hu Y, et al. Clinical features of patients infected with 2019 novel coronavirus in Wuhan, China. Lancet 2020 Feb;395(10223):497-506. [doi: 10.1016/s0140-6736(20)30183-5]

13. Fang Y, Zhang H, Xie J, Lin M, Ying L, Pang P, et al. Sensitivity of Chest CT for COVID-19: Comparison to RT-PCR. Radiology 2020 Aug;296(2):E115-E117 [FREE Full text] [doi: 10.1148/radiol.2020200432] [Medline: 32073353]

14. Ai T, Yang Z, Hou H, Zhan C, Chen C, Lv W, et al. Correlation of Chest CT and RT-PCR Testing for Coronavirus Disease 2019 (COVID-19) in China: A Report of 1014 Cases. Radiology 2020 Aug;296(2):E32-E40 [FREE Full text] [doi: 10.1148/radiol.2020200642] [Medline: $\underline{\text { 32101510] }}$ 
15. Hao W, Li M. Clinical diagnostic value of CT imaging in COVID-19 with multiple negative RT-PCR testing. Travel Med Infect Dis 2020 Mar;34:101627 [FREE Full text] [doi: 10.1016/j.tmaid.2020.101627] [Medline: 32179123]

16. Araujo-Filho J, Sawamura MVY, Costa AN, Cerri GG, Nomura CH. COVID-19 pneumonia: what is the role of imaging in diagnosis? J Bras Pneumol 2020 Mar 27;46(2):e20200114 [FREE Full text] [doi: 10.36416/1806-3756/e20200114] [Medline: $\underline{\text { 32236303] }}$

17. Yang W, Sirajuddin A, Zhang X, Liu G, Teng Z, Zhao S, et al. The role of imaging in 2019 novel coronavirus pneumonia (COVID-19). Eur Radiol 2020 Apr 15:online [FREE Full text] [doi: 10.1007/s00330-020-06827-4] [Medline: 32296940]

18. Wong H, Lam H, Fong A, Leung S, Chin T, Lo C, et al. Frequency and Distribution of Chest Radiographic Findings in Patients Positive for COVID-19. Radiology 2020 Aug;296(2):E72-E78 [FREE Full text] [doi: 10.1148/radiol.2020201160] [Medline: 32216717]

19. Ng M, Lee EY, Yang J, Yang F, Li X, Wang H, et al. Imaging Profile of the COVID-19 Infection: Radiologic Findings and Literature Review. Radiology: Cardiothoracic Imaging 2020 Feb 01;2(1):e200034. [doi: 10.1148/ryct.2020200034]

20. Bernheim A, Mei X, Huang M, Yang Y, Fayad ZA, Zhang N, et al. Chest CT Findings in Coronavirus Disease-19 (COVID-19): Relationship to Duration of Infection. Radiology 2020 Jun;295(3):200463 [FREE Full text] [doi: 10.1148/radiol.2020200463] [Medline: 32077789]

21. Pan F, Ye T, Sun P, Gui S, Liang B, Li L, et al. Time Course of Lung Changes at Chest CT during Recovery from Coronavirus Disease 2019 (COVID-19). Radiology 2020 Jun;295(3):715-721. [doi: 10.1148/radiol.2020200370]

22. Salehi S, Abedi A, Balakrishnan S, Gholamrezanezhad A. Coronavirus Disease 2019 (COVID-19): A Systematic Review of Imaging Findings in 919 Patients. AJR Am J Roentgenol 2020 Jul;215(1):87-93. [doi: 10.2214/ajr.20.23034]

23. Li B, Li X, Wang Y, Han Y, Wang Y, Wang C, et al. Diagnostic value and key features of computed tomography in Coronavirus Disease 2019. Emerg Microbes Infect 2020 Dec 23;9(1):787-793 [FREE Full text] [doi: 10.1080/22221751.2020.1750307] [Medline: 32241244]

24. Kooraki S, Hosseiny M, Myers L, Gholamrezanezhad A. Coronavirus (COVID-19) Outbreak: What the Department of Radiology Should Know. J Am Coll Radiol 2020 Apr;17(4):447-451 [FREE Full text] [doi: 10.1016/j.jacr.2020.02.008] [Medline: 32092296]

25. Pan Y, Guan H, Zhou S, Wang Y, Li Q, Zhu T, et al. Initial CT findings and temporal changes in patients with the novel coronavirus pneumonia (2019-nCoV): a study of 63 patients in Wuhan, China. Eur Radiol 2020 Jun 13;30(6):3306-3309 [FREE Full text] [doi: 10.1007/s00330-020-06731-x] [Medline: 32055945]

26. Zhao W, Zhong Z, Xie X, Yu Q, Liu J. CT Scans of Patients with 2019 Novel Coronavirus (COVID-19) Pneumonia. Theranostics 2020;10(10):4606-4613 [FREE Full text] [doi: 10.7150/thno.45016] [Medline: 32292517]

27. Xie X, Zhong Z, Zhao W, Zheng C, Wang F, Liu J. Chest CT for Typical Coronavirus Disease 2019 (COVID-19) Pneumonia: Relationship to Negative RT-PCR Testing. Radiology 2020 Aug;296(2):E41-E45 [FREE Full text] [doi: 10.1148/radiol.2020200343] [Medline: 32049601]

28. Yoon S, Lee K, Kim J, Lee Y, Ko H, Kim K, et al. Chest Radiographic and CT Findings of the 2019 Novel Coronavirus Disease (COVID-19): Analysis of Nine Patients Treated in Korea. Korean J Radiol 2020 Apr;21(4):494-500 [FREE Full text] [doi: $10.3348 / \mathrm{kjr} .2020 .0132]$ [Medline: $\underline{\text { 32100485] }}$

29. Wang K, Kang S, Tian R, Zhang X, Zhang X, Wang Y. Imaging manifestations and diagnostic value of chest CT of coronavirus disease 2019 (COVID-19) in the Xiaogan area. Clin Radiol 2020 May;75(5):341-347 [FREE Full text] [doi: 10.1016/j.crad.2020.03.004] [Medline: 32216961$]$

30. Zhao W, Zhong Z, Xie X, Yu Q, Liu J. Relation Between Chest CT Findings and Clinical Conditions of Coronavirus Disease (COVID-19) Pneumonia: A Multicenter Study. AJR Am J Roentgenol 2020 May;214(5):1072-1077. [doi: 10.2214/ajr.20.22976]

31. Zhou Z, Guo D, Li C, Fang Z, Chen L, Yang R, et al. Coronavirus disease 2019: initial chest CT findings. Eur Radiol 2020 Aug;30(8):4398-4406 [FREE Full text] [doi: 10.1007/s00330-020-06816-7] [Medline: 32211963]

32. Chung M, Bernheim A, Mei X, Zhang N, Huang M, Zeng X, et al. CT Imaging Features of 2019 Novel Coronavirus (2019-nCoV). Radiology 2020 Apr;295(1):202-207 [FREE Full text] [doi: 10.1148/radiol.2020200230] [Medline: 32017661]

33. Koo HJ, Lim S, Choe J, Choi S, Sung H, Do K. Radiographic and CT Features of Viral Pneumonia. Radiographics 2018 May;38(3):719-739. [doi: 10.1148/rg.2018170048] [Medline: 29757717]

34. Jin Y, Cai L, Cheng Z, Cheng H, Deng T, Fan YP, for the Zhongnan Hospital of Wuhan University Novel Coronavirus Management and Research Team, Evidence-Based Medicine Chapter of China International Exchange and Promotive Association for Medical and Health Care (CPAM). A rapid advice guideline for the diagnosis and treatment of 2019 novel coronavirus (2019-nCoV) infected pneumonia (standard version). Mil Med Res 2020 Feb 06;7(1):4 [FREE Full text] [doi: 10.1186/s40779-020-0233-6] [Medline: 32029004]

35. Long C, Xu H, Shen Q, Zhang X, Fan B, Wang C, et al. Diagnosis of the Coronavirus disease (COVID-19): rRT-PCR or CT? Eur J Radiol 2020 May;126:108961 [FREE Full text] [doi: 10.1016/j.ejrad.2020.108961] [Medline: 32229322]

36. Shi H, Han X, Jiang N, Cao Y, Alwalid O, Gu J, et al. Radiological findings from 81 patients with COVID-19 pneumonia in Wuhan, China: a descriptive study. Lancet Infect Dis 2020 Apr;20(4):425-434. [doi: 10.1016/s1473-3099(20)30086-4] 
37. Raptis C, Hammer M, Short R, Shah A, Bhalla S, Bierhals A, et al. Chest CT and Coronavirus Disease (COVID-19): A Critical Review of the Literature to Date. AJR Am J Roentgenol 2020 Apr 16:1-4. [doi: 10.2214/AJR.20.23202] [Medline: $\underline{32298149]}$

38. Rubin GD, Ryerson CJ, Haramati LB, Sverzellati N, Kanne JP, Raoof S, et al. The Role of Chest Imaging in Patient Management during the COVID-19 Pandemic: A Multinational Consensus Statement from the Fleischner Society. Radiology $2020 \mathrm{Jul}$;296(1):172-180 [FREE Full text] [doi: 10.1148/radiol.2020201365] [Medline: 32255413]

39. Lei D, Li C, Fang C, Yang W, Cheng B, Wei M. Clinical characteristics of pregnancy with the 2019 novel coronavirus disease (COVID-19) infection. Article in Chinese. Chinese Journal of Perinatal Medicine 2020;23(3):online.

40. Liu H, Liu F, Li J, Zhang T, Wang D, Lan W. Clinical and CT imaging features of the COVID-19 pneumonia: Focus on pregnant women and children. J Infect 2020 May;80(5):e7-e13 [FREE Full text] [doi: 10.1016/j.jinf.2020.03.007] [Medline: $\underline{32171865]}$

41. ACR Recommendations for the use of Chest Radiography and Computed Tomography (CT) for Suspected COVID-19 Infection. American College of Radiology. 2020 Mar 22. URL: https://www.acr.org/Advocacy-and-Economics/ ACR-Position-Statements/Recommendations-for-Chest-Radiography-and-CT-for-Suspected-COVID19-Infection [accessed 2020-08-04]

42. Song F, Shi N, Shan F, Zhang Z, Shen J, Lu H, et al. Emerging 2019 Novel Coronavirus (2019-nCoV) Pneumonia. Radiology 2020 Apr;295(1):210-217 [FREE Full text] [doi: 10.1148/radiol.2020200274] [Medline: 32027573]

43. Lomoro P, Verde F, Zerboni F, Simonetti I, Borghi C, Fachinetti C, et al. COVID-19 pneumonia manifestations at the admission on chest ultrasound, radiographs, and CT: single-center study and comprehensive radiologic literature review. Eur J Radiol Open 2020;7:100231 [FREE Full text] [doi: 10.1016/j.ejro.2020.100231] [Medline: 32289051]

44. Jacobi A, Chung M, Bernheim A, Eber C. Portable chest X-ray in coronavirus disease-19 (COVID-19): A pictorial review. Clin Imaging 2020 Aug;64:35-42 [FREE Full text] [doi: 10.1016/j.clinimag.2020.04.001] [Medline: 32302927$]$

45. Zu Z, Jiang M, Xu P, Chen W, Ni Q, Lu G, et al. Coronavirus Disease 2019 (COVID-19): A Perspective from China. Radiology 2020 Aug;296(2):E15-E25 [FREE Full text] [doi: 10.1148/radiol.2020200490] [Medline: 32083985]

46. Capitanio S, Nordin AJ, Noraini AR, Rossetti C. PET/CT in nononcological lung diseases: current applications and future perspectives. Eur Respir Rev 2016 Sep 31;25(141):247-258 [FREE Full text] [doi: 10.1183/16000617.0051-2016] [Medline: $\underline{27581824]}$

47. Lütje S, Marinova M, Kütting D, Attenberger U, Essler M, Bundschuh RA. Nuclear medicine in SARS-CoV-2 pandemia: 18F-FDG-PET/CT to visualize COVID-19. Nuklearmedizin 2020 Jun;59(3):276-280 [FREE Full text] [doi: 10.1055/a-1152-2341] [Medline: 32259853]

48. Qin C, Liu F, Yen T, Lan X. F-FDG PET/CT findings of COVID-19: a series of four highly suspected cases. Eur J Nucl Med Mol Imaging 2020 May 22;47(5):1281-1286 [FREE Full text] [doi: 10.1007/s00259-020-04734-w] [Medline: 32088847]

49. Zou S, Zhu X. FDG PET/CT of COVID-19. Radiology 2020 Aug;296(2):E118-E118 [FREE Full text] [doi: 10.1148/radiol.2020200770] [Medline: 32142399]

50. Czernin J, Fanti S, Meyer P, Allen-Auerbach M, Hacker M, Sathekge M, et al. Nuclear Medicine Operations in the Times of COVID-19: Strategies, Precautions, and Experiences. J Nucl Med 2020 May;61(5):626-629. [doi: 10.2967/jnumed.120.245738] [Medline: 32238430]

51. Deng Y, Lei L, Chen Y, Zhang W. The potential added value of FDG PET/CT for COVID-19 pneumonia. Eur J Nucl Med Mol Imaging $2020 \mathrm{Jul}$ 21;47(7):1634-1635 [FREE Full text] [doi: 10.1007/s00259-020-04767-1] [Medline: 32198615]

52. Ayan A, Kıraç FS. Guide for Nuclear Medicine Applications During the COVID-19 Outbreak. Mol Imaging Radionucl Ther 2020 Apr 29;29(2):49-58 [FREE Full text] [doi: 10.4274/mirt.galenos.2020.33600] [Medline: $\underline{32368875}$ ]

53. Laursen CB, Sloth E, Lassen AT, Christensen RD, Lambrechtsen J, Madsen PH, et al. Point-of-care ultrasonography in patients admitted with respiratory symptoms: a single-blind, randomised controlled trial. Lancet Respir Med 2014 Aug;2(8):638-646. [doi: 10.1016/s2213-2600(14)70135-3]

54. Zhou B, Bartholmai BJ, Kalra S, Osborn TG, Zhang X. Lung US Surface Wave Elastography in Interstitial Lung Disease Staging. Radiology 2019 May;291(2):479-484 [FREE Full text] [doi: 10.1148/radiol.2019181729] [Medline: 30835191]

55. Mojoli F, Bouhemad B, Mongodi S, Lichtenstein D. Lung Ultrasound for Critically Ill Patients. Am J Respir Crit Care Med 2019 Mar 15;199(6):701-714. [doi: 10.1164/rccm.201802-0236ci]

56. Convissar D, Gibson L, Berra L, Bittner E, Chang M. Application of Lung Ultrasound During the COVID-19 Pandemic: A Narrative Review. Anesth Analg 2020 Aug;131(2):345-350 [FREE Full text] [doi: 10.1213/ANE.0000000000004929] [Medline: 32366774]

57. Peng Q, Wang X, Zhang L, Chinese Critical Care Ultrasound Study Group (CCUSG). Findings of lung ultrasonography of novel corona virus pneumonia during the 2019-2020 epidemic. Intensive Care Med 2020 May 12;46(5):849-850 [FREE Full text] [doi: 10.1007/s00134-020-05996-6] [Medline: $\underline{32166346]}$

58. Sofia S, Boccatonda A, Montanari M, Spampinato M, D'ardes D, Cocco G, et al. Thoracic ultrasound and SARS-COVID-19: a pictorial essay. J Ultrasound 2020 Jun 16;23(2):217-221 [FREE Full text] [doi: 10.1007/s40477-020-00458-7] [Medline: $\underline{32297175]}$ 
59. Buonsenso D, Piano A, Raffaelli F, Bonadia N, de Gaetano Donati K, Franceschi F. Point-of-Care Lung Ultrasound findings in novel coronavirus disease-19 pnemoniae: a case report and potential applications during COVID-19 outbreak. Eur Rev Med Pharmacol Sci 2020 Mar;24(5):2776-2780 [FREE Full text] [doi: 10.26355/eurrev 202003 20549] [Medline: 32196627]

60. Lin H, Zhang B, Kou H, Zhao Y, Li K, Wu D. Application value of lung ultrasound in asymptomatic patients with confirmed COVID-19. AUDT 2020;4(2):67-72 [FREE Full text]

61. Vetrugno L, Bove T, Orso D, Barbariol F, Bassi F, Boero E, et al. Our Italian experience using lung ultrasound for identification, grading and serial follow-up of severity of lung involvement for management of patients with COVID-19. Echocardiography 2020 Apr 15;37(4):625-627 [FREE Full text] [doi: 10.1111/echo.14664] [Medline: $\underline{32239532}$ ]

62. Moro F, Buonsenso D, Moruzzi MC, Inchingolo R, Smargiassi A, Demi L, et al. How to perform lung ultrasound in pregnant women with suspected COVID-19. Ultrasound Obstet Gynecol 2020 May;55(5):593-598. [doi: 10.1002/uog.22028] [Medline: $\underline{\text { 32207208] }}$

63. Li X, Zeng W, Li X, Chen H, Shi L, Li X, et al. CT imaging changes of corona virus disease 2019 (COVID-19): a multi-center study in Southwest China. J Transl Med 2020 Apr 06;18(1):154 [FREE Full text] [doi: 10.1186/s12967-020-02324-w] [Medline: 32252784$]$

64. Li Y, Xia L. Coronavirus Disease 2019 (COVID-19): Role of Chest CT in Diagnosis and Management. AJR Am J Roentgenol 2020 Jun;214(6):1280-1286. [doi: 10.2214/AJR.20.22954] [Medline: 32130038]

65. Lu W, Zhang S, Chen B, Chen J, Xian J, Lin Y, et al. A Clinical Study of Noninvasive Assessment of Lung Lesions in Patients with Coronavirus Disease-19 (COVID-19) by Bedside Ultrasound. Ultraschall Med 2020 Jun 15;41(3):300-307. [doi: 10.1055/a-1154-8795] [Medline: 32294796]
Abbreviations
ACR: American College of Radiology
ARDS: adult respiratory distress syndrome
COVID-19: coronavirus disease
CT: computed tomography
FDG: fluorodeoxyglucose
GGO: ground-glass opacity
MERS: Middle East respiratory syndrome
MERS-CoV: Middle East respiratory syndrome coronavirus
NCP: novel coronavirus pneumonia
PET/CT: positron emission topography/computed tomography
RT-PCR: reverse transcription-polymerase chain reaction
SARS: severe acute respiratory syndrome
SARS-CoV: severe acute respiratory syndrome coronavirus
SARS-CoV-2: severe acute respiratory syndrome coronavirus 2
SUV max: maximum standardized uptake value
WHO: World Health Organization

Edited by G Eysenbach; submitted 27.04.20; peer-reviewed by A Tajaldeen, I Abdelaziz, P Lei; comments to author 15.06.20; revised
version received 28.06.20; accepted 21.07.20; published 19.08.20
Please cite as:
Aljondi R, Alghamdi S
Diagnostic Value of Imaging Modalities for COVID-19: Scoping Review
J Med Internet Res 2020;22(8):e19673
URL: $\underline{\text { http://www.jmir.org/2020/8/e19673/ }}$
doi: $\underline{10.2196 / 19673}$
PMID: $\underline{32716893}$

CRowa Aljondi, Salem Alghamdi. Originally published in the Journal of Medical Internet Research (http://www.jmir.org), 19.08.2020. This is an open-access article distributed under the terms of the Creative Commons Attribution License (https://creativecommons.org/licenses/by/4.0/), which permits unrestricted use, distribution, and reproduction in any medium, provided the original work, first published in the Journal of Medical Internet Research, is properly cited. The complete bibliographic information, a link to the original publication on http://www.jmir.org/, as well as this copyright and license information must be included. 